\title{
Tajdidukasi
}

Vol. 9, No. 1, January 2019, pp. 19-28

\section{Konseling perkawinan: Strategi preventif penanganan problem relasi keluarga dan membangun hubungan keluarga yang sakinah}

\author{
Casmini Casmini \\ Universitas Islam Negeri Sunan Kalijaga Yogyakarta. Jalan Marsda Adisucipto, Yogyakarta, 55281, Indonesia \\ casminiuin@gmail.com \\ * corresponding author
}

\section{ARTICLE INFO}

\section{Keywords}

konseling perkawinan

problem relasi keluarga

keluarga sakinah

\begin{abstract}
Tulisan ini bertujuan untuk mendeskripsikan dan menganalisis peran konseling perkawinan dalam penanganan problem relasi keluarga dan membangun hubungan keluarga yang sakinah. Metode yang digunakan library research dengan teknik analisis data menggunakan deskriptif kualitatif. Hasil penelitian menunjukkan bahwa problematika relasi keluarga semakin komplek sehingga mengakibatkan ketidakharmonisan dalam keluarga. Upaya yang dapat digunakan untuk mencegah dan mengurangi problem relasi keluarga adalah melalui layanan konseling perkawinan. Konseling perkawinan diarahkan pada lima tahap orientasi yaitu memahami makna keluarga, meningkatkan kesadaran dan dinamika keluarga, komunikasi dan terapi, membangun interaksi dan relasi keluarga, penanganan problem keluarga, membina hubungan keluarga melalui gaya kelekatan keluarga. Lima orientasi ini menjadi upaya preventif mengurangi dan menangani problem relasi keluarga, selanjutnya dapat digunakan sebagai salah satu strategi membangun hubungan keluarga yang sakinah.
\end{abstract}

This is an open access article under the CC-BY-SA license.

\section{PENDAHULUAN}

Kehidupan keluarga, tidak selalu dapat berjalan dengan baik dan mulus. Banyak keluarga yang mengalami problem dalam kehidupan perkawinan. Data yang dilansir beberapa media menunjukkan semakin tinggi dan kompleknya persoalan yang dihadapi keluarga, mulai dari kekerasan, kejahatan, hingga pada kasus kriminalitas dalam kehidupan keluarga. Komnas perempuan menyebutkan bahwa, terdapat trend kenaikan jumlah kasus kekerasan terhadap perempuan dan anak dalam lingkup kehidupan keluarga. Peningkatan kasus dapat dilihat setiap tahunnya, Tahun 2010 sebesar 101.128, tahun 2011 total kekerasan dalam rumah tangga (KDRT) sebesar 12.999, dan Kekerasan Terhadap Anak dan Perempuan (KTPA) sebesar 660. Pada tahun 2012 total kasus KDRT 13.771, dan KTAP 1311. Tahun 2013 tercatat kasus kekerasan sebanyak 211.131. Peningkatan kasus kekerasan juga terjadi pada tahun 2014. Data Komnas PRPA tahun 2014 berjumlah 279.760 kasus. Women Crisis Centre (WCC) menyebutkan pada Tahun 2014 terdapat 293.220 kasus kekerasan terhadap perempuan dan anak peningkatan kasus kekerasan juga terjadi pada tahun 2015 sebanyak 321.752 atau meningkat 9 (sembilan) persen dari tahun 2014. Semakin tingginya kasus kekerasan terhadap perempuan dan anak ini menunjukkan Indikasi bahwa telah terjadi problem dalam kehidupan perkawinan (Umriana et al., 2017). 
Problem kehidupan perkawinan dapat disebabkan dari berbagai faktor, baik faktor internal maupun eksternal. Faktor internal basanya menjadi faktor penentu lahirnya problem dalam keluarga. Tidak banyak dari anggota keluarga memahami pentingnya relasi keluarga dalam kehidupan perkawinan. Padahal relasi dalam keluarga menjadi prasyarat adanya ikatan perkawinan. Semua hubungan perkawinan ditandai dengan relasi antara individu dengan iindividu lainnya, sub system dengan subsistem lainnya. Problem relasi keluarga dapat ditemukan dalam beberapa kasus relasi setiap keluarga. Nicholas dan Schwartz dalam Kathryn Geldard dan David Geldard menyebutkan bahwa relasi keluarga yang tidak kondusif menjadi sumber potensial terjadinya ketidakharmonisan keluarga (Geldard, 2009). Relasi seorang ayah dengan ibu, apabila tidak berjalan baik, cenderung melahirkan konflik baik untuk dirinya sendiri maupun anak-anaknya, sehingga menimbulkan kondisi tegang dan rawan konflik. Ini terjadi karena ayah dan ibu dalam subsistem tidak hanya memainkan peran sebagai pasangan (suami dan istri), melainkan ada dalam subsistem gabungan sebagai orang tua dari subsistem anak-anaknya. Subsistem perkawinan atau pasangan berbeda dengan subsistem sebagai orang tua, karen atugas dan tanggung jawabnya juga berbeda. Apabila masing-masing subsistem tidak ada kesesuaian, maka terjadi problem relasi.

Problem relasi keluarga perlu ditangani dengan baik dan efektif, melalui model dan teknik terapi. Salah satu upaya terapi yang dapat dilakukan dengan konseling perkawinan. Konseling perkawinan merupakan proses terapis berorinetasi pada pencegahan dan penanganan masalah dalam kehidupan perkawinan. Proses terapi dalam konseling perkawinan dapat memanfaatkan fungsi dan model terapi keluarga, yang mendasarkan pada relasi antar subsistem keluarga. Ini menjadi salah satu langkah penting, karena pada terapi ini keluarga dan masing-masing anggotanya diarahkan untuk mendapatkan pemahaman, kesadaran mengenai makna keluarga, problem relasi keluarga, dinamika keluarga, hingga solusi yang dapat diperoleh dan dikebangkan secara mandiri oleh masing-masing keluarga. Tulisan ini selanjutya akan mendeskripsikan dan menganalisis konseling perkawinan sebagai strategi penanganan problem relasi keluarga dan membangun keluarga sakinah. Untuk mencapai tujuan, maka tulisan ini menggunakan pendekatan aspek psikologi sosial dengan teknik analisis data kulitatif.

\section{Makna dan Problem Relasi Keluarga}

Keluarga merupakan sistem sosial yang memiliki keunikan dalam proses interaksinya. Proses interaksi yang dibangun dalam keluarga bertujuan untuk memenuhi kebutuhan-kebutuhan para anggotanya. Pola interaksi dalam relasi keluarga juga berfungsi untuk memperoleh kebahagiaan (Lubis, 2007). Etzioni (1993) menyebutkan bahwa kehidupan keluarga yang kuat menciptakan masyarakat yang kuat, sebaliknya kehidupan keluarga yang lemah, menciptakan masyarakat yang lemah. Keluarga menjadi unit fundamental sebuah masyarakat, karena dari keluargalah menjadi salah satu perwujudan kesejahteraan hidup kelompok manusia, bangsa dan negara (Etzioni, 1994). Kehidupan keluarga sebagai sebuah system, memiliki pola interaksi yang berbeda dalam setiap levelnya. Kecenderungan interaksi ini tidak jarang menimbulkan problem yang begitu serius dalam kehidupan keluarga.

Problem interaksi pada level yang berbeda memiliki corak dan pola yang berbeda pula. Terdapat empat tingkatan interaksi dalam keluaga, subsistem orang tua, perkawinan, anak yang lebih tua, dan subsistem anak yang lebih muda. Pada level orang tua sering disebut level pengasuhan. Orang tua mempertanggungjawabkan semua aspek pengasuhan. Problem yang sering muncul adalah pengasuhan yang tepat dan baik oleh orang tua. Orang tua pada subsistem ini perlu mengetahui batas-batas spesifik untuk mengatur kehidupan anak-anaknya, bagaimana memposisikan peran anak dlam keluarga. Terdapat dua persoalan dalam pengasuhan oramg tua pada anak. Pola pengawasan dan pengaturan yang bersifat keras dan longgar. Pada tipe pengasuhan keras simungkinkan terjadinya konflik internal dengan anak, sebaliknya tipe longgar dapat menjadi peluang bagi anak untuk membangun kontak sosial, psikologis, dan fisik yang bersifat kasih saying dan distribusi pembagian informasi yang pantas bagi anak-anaknya.

Level kedua disebut sebagai level perkawinan atau pasangan (suami dan istri). Problem yang sering muncul pada subsistem orang tua adalah tingkat pengendalian relasi pribadi, dan intimitas. Pengendalian relasi pribadi ditandai dari karakter dan kepribadian masing-masing individu dalam keluarga. Individu-individu dugabungkan secara emosional, psikis, dan sosial. Pengendalian emosional 
dan psikis merupakan komponen abstrak yang memiliki kontribusi dalam terbangunnya rasa aman, nyaman, kebahagiaan bagi anggota keluarga. Pada pengendalian sosial, individu-individu diikat melalui aturan dan pembatasan keluarga yang digunakan untuk keperluan memahami cara kerja system (Etzioni, 1994). Pembatasan pada keluarga ini merupakan pengendalian yang bertujuan melindungi kemandirian dan otonomi keluarga berserta subsistemnya. Persoalan yang muncul dalam pengendalian relasi pribadi berkaitan dengan persoalan egoisitas masing-masing individu sebagai pasangan (suami istri). Ada indikasi permaianan peran dan tanggung jawab berbeda, sehingga menimbulkan ketidakpuasan secara emosional, psikis, dan sosial.

Pada pengendalian intimitas berkaitan dengan hubungan keintiman antara pasangan (suami dan istri). Hubungan keintiman dalam aspek biologis, maupun emosional dan sosial. keintiman biologis berkenaan dengan persoalan reproduksi dan pengasuhan, sedangkan keintiman secara emosional dan sosial mengarah pada gaya kelekatan pasangan. Problem yang sering muncul pada relasi keintiman ini berkaitan dengan penentuan proses reproduksi dan persoalan penghormatan isu kekuasaaan dan keintiman yang bersifat kaku. Kekuasaan dan keintiman yang kaku memunculkan ketegangan dan rawan konflik. Idealnya relasi kuasa dan keintiman dilaksanakan secara longgar, dan selalu dinegosiasikan. Proses negosiasi menjadikan interaksi antar anggota keluarga menjadi dinamis, dan mempengaruhi cara bagaimana keluarga berfungsi. Islam menganjurkan kepada setiap umatnya selalu menjalankan negosiasi dengan cara yang baik seperti dijelakan dalam quran surat an Nisa ayat 1, 4, dan an Nahl ayat 125 .

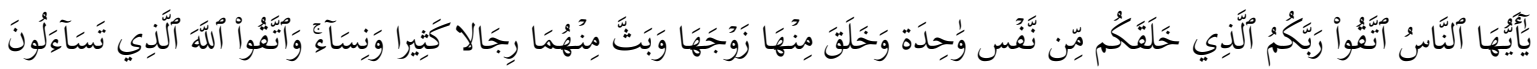

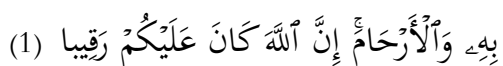

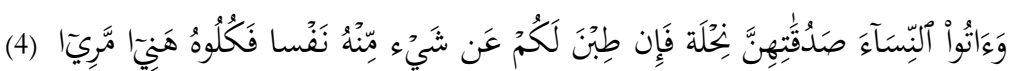

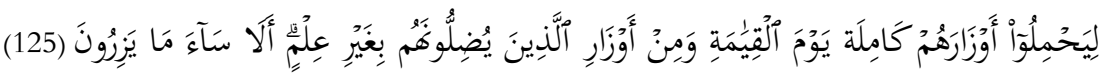

"Hai sekalian manusia, bertakwalah kepada Tuhan-mu yang telah menciptakan kamu dari seorang diri, dan dari padanya Allah menciptakan isterinya; dan dari pada keduanya Allah memperkembang-biakkan laki-laki dan perempuan yang banyak, dan bertakwalah kepada Allah yang dengan (mempergunakan) nama-Nya kamu saling meminta satu sama lain, dan (peliharalah) hubungan silaturrahim. Sesungguhnya Allah selalu menjaga dan mengawasi kamu".

"berikanlah maskawin (mahar) kepada wanita (yang kamu nikahi) sebagai pemberian dengan penuh kerelaan kemudian jika mereka menyerahkan kepada kamu sebagian dari maskawin itu dengan senang hati, Maka makanlah (ambillah) pemberian itu (sebagai makanan) yang sedap lagi baik akibatnya."

"serulah (manusia) kepada jalan Tuhan-mu dengan hikmah dan pelajaran yang baik dan bantahlah mereka dengan cara yang baik. Sesungguhnya Tuhanmu Dialah yang lebih mengetahui tentang siapa yang tersesat dari jalan-Nya dan Dialah yang lebih mengetahui orang-orang yang mendapat petunjuk."

Ayat tersebut menunjukkan bahwa negosiasi menjadi hal penting dalam keluarga. Negosiasi ditunjukkan dalam beberapa hal melakukan memelihara hubungan silaturrahmi, berbagai hal dengan kerelaan, berdiskusi dengan cara yang baik (Thanthawi et al., 2001). negosiasi menjadi salah satu bentuk pola pengendalian keintiman, karena di dalamnya mencakup kerjasama atau kolaborasi saling menguntungkan antar pasangan seperti Gambar 1.

\begin{tabular}{|c|ll|}
\multicolumn{2}{c|}{ Keintiman } & \\
\hline Longgar & \multicolumn{2}{c|}{ Terikat } \\
\hline Kaku & $\mathrm{x}$ & Terlepas \\
\hline
\end{tabular}

Kekuasaan

Gambar 1. Kolaborasi Interaksi Hubungan 
Gambar 1 menunjukkan bagaimana pengendalian relasi dan keintiman ada dalam keluarga. Adanya penghargaan terhadap keintiman, menghasilkan kehangatan, saling berbagi emosi, empati, dukungan, dan kelekatan. Keluarga yang demikian, akan menjadikan anggotanya terikat dalam keintiman, sehingga terjalin komunikasi yang tinggi diantara para anggota keluarga. Kekuasaan dipergunaakan untuk mengontrol perilaku anggotanya. Penghargaan terhadap kekuasaaan menjadikan seluruh keluarga memiliki aturan yang bersifat longgar (laissez-faire), dimana hanya ada sedikit aturan dan anggota dapat melakukan apa yang mereka inginkan. Kontribusi dari kerjasama ini sangat baik untuk meningkatkan kekuatan keluarga. Howe dalam Kathryn Geldard dan David Geldard (2011) menyebutkan bahwa kerjasama pasangan melahirkan dukungan. Kualitas hubungan dapat diperoleh dari sikap hangat, mendukung, penuh perhatian, berempati, klarifikatif, keterlibatan partisipatif, membantu, kolaboratif, dan menciptakan keharmonisan atau keselarasan hubungan (Geldard \& Geldard, 2011).

Problem relasi pada level selanjutnya adalah subsistem saudara tua dan muda. Level ini menjelaskan pola relasi antar saudara kandung. Pengendalian pada level ini bersifat menyerap perhatian, karena akan terjadi saling relasi anak-anak dan berbasis gender. Subsistem ini akan memberikaan keuntungan dan kerugian. Keuntungan interaksi antar subsistem mengkondisikan para anggota keluarga saling mendukung dalam aktivitas dan pemenuhan kebutuhan. Kerugiannya apabila dilihat dari pola pengasuhan yang bersifat kaku, cenderung menjadikan anak-anak merasa tertekan, rawan konflik, dan salah asuh. Keluarga dalam konteks ini tentu harus memahami dengan benar setiap pembatasan antar anak, dilakukan pembatasan yang tepat dengan artian bahwa perintang bukan terletak pada mengatur jumlah dan jenis kontak, tetapi melindungi dengan memunculkan kemandirian pada peran masingmasing anggota keluarga, terutama peran anak lebih tua dan muda dalam Gambar 2.

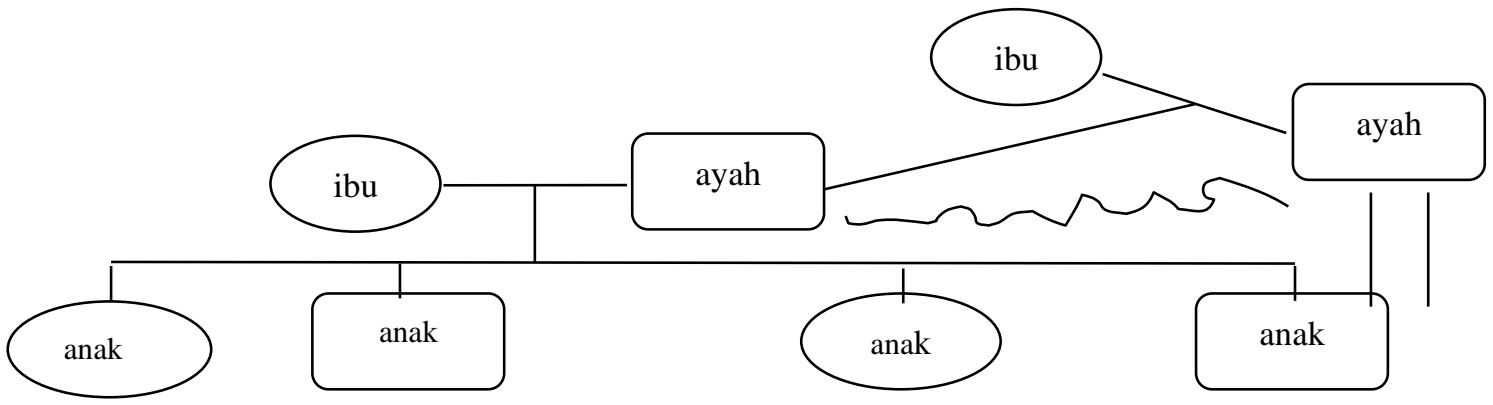

Gambar 2. Aliansi keluarga

Gambar 2 menunjukkan aliansi yang terjadi pada satu unit keluarga. Aliansi digambarkan sebagai susunan kooperatif beberapa subsistem, yaitu system orang tua, perkawinan, subsistem anaak lebih tua dan lebih muda. Subsistem tersebut memungkinkan keterlibatan anggota keluarga dalam aktivitas partisipatif dan pemenuhan kebutuhan. Problem yang sering muncul dalam aliansi tersebut adalah penyisihan atau pengasingan sebagian partner (bisa ayah, ibu dan atau anak-anaknya). Problem ini menghasilkan konflik antar kedua orang tua, atau anak-anaknya. Resiko lebih luas dapat menurunkan kualitas aliansi, terlebih pada pola aliansi lintas generasi.

\section{Kesadaran dan dinamika keluarga}

Kualitas keluarga ditunjukkan dengan adanya kesadaran atas aliansi dari keluarga itu sendiri. Kesadaran menjadi upaya mengembangkan wacana antar anggota keluarga, dan memungkinkan anggota keluarga saling berbagi persepsi individualnya. Kesadaran juga berguna untuk memahami relasi-relasi yang terjadi dalam keluarga. Ini membuktikan bahwa keberhasilan keluarga sangat ditentukan oleh kualitas anggotanya melalui aspek penyadaran (Hariwijaya, 2011). Hasanah (2013) menyebutkan bahwa kesadaran merupakan aspek penting bagi diri seseorang untuk mengembangkan potensi individualnya (Hasanah, 2013). Kesadaran yang tinggi diwujudkan dalam aspek afektif, kognitif, dan psikomotorik yang handal. Kesadaran dalam aspek afektif berarti memunculkan sikap terbuka, mau dan memahami potensi diri, dan selalu menjaga sikap sesuai dengan nilai-nilai sosial agama. Kesadaran afektif dalam konteks keluarga berarti keyakinan positif mengenai nilai-nilai dan fungsi kekeluargaan. Penyadaran terhadap nilai-nilai dan fungsi keluarga menjadikan para anggotanya memiliki kekuatan untuk selalu menghadirkan pemahaman positif mengenai keluarganya. Kondisi 
ini menyangkut relasi dan perilaku anggota keluarga, yaitu mengenali perilaku antar generasi, perhatian terhadap aliansi dan koalisi, memahami dan menyadari pengendalian dan struktur dalam keluarga. Kesadaran dalam konsep kognitif berarti memahami dan menyadari bahwa keluarga adalah sumber kekuatan. Kekuatan selannjutnya digunakan untuk mengembangkan potensi keluarga dalam memenuhi kebutuhan material dan spiritual. Kesadaran dalam konteks psikomotorik berkaitan erat dengan persoalan konsistensi perilaku. Keluarga yang berkualitas selalu menghadirkan perilaku positif, dan kehidupan yang berakhlak.

Kesadaran lainnya berkenaan dengan peran dan fungsi keluarga bagi kehidupan anggota. Keluarga menjadi subsistem pemenuhan kebutuhan anggota keluarga, lingkungan pengasuhan dan reproduksi yang sehat, media interaksi dan komunikasi, perwujudak kesejahteraan sosial. Keluarga sebagai subsistem berarti pemahaman bahwa keluarga adalah alternative potensial dalam memenuhi kebutuhan seperti keamanan dan keselamatan, kesejahteraan ekonomi dan materi, psikologis, fisik, dan emosional, serta kebutuhan spiritual. Keluraga sebagai lingkungan pengasuhan dan reproduksi karena keluarga merupakan lingkungan kondusif untuk menjalani tahap perkembangan dan pertumbuhan anakanaknya melalui pengajaran maupun peragaan dan keteladanan. Kesadaran interaksi dan komunikasi dalam hal ini berkenaan dengan sumber informasi dan pemenuhan kebutuhan keluarga. Interasi dan komunikasi berkaitan dengan jaringan system dalam kehidupan sosial, karena keluarga adalah unit terkecil alam masyarakat. Keluarga menjadi media mewujudkan kesejahteraan komunitas melalui komunikasi dan interaksi sosial. Proses sirluler dari interaksi dan komunikasi mendukung kesejahteraan unit keluarga.

Cara berfungsi suatu keluarga dipengaruhi sejumlah faktor antara lain tahap perkembangan keluarga, budaya/ etnsitas, proses dan perilaku dalam keluarga. Keluarga dibentuk dan berkembang dengan cara berbeda, dimulai dari dua orang berlainan jenis melibatkan diri sebagai pasangan keluarga, lahirnya anak dalam keluarga, pertumbuhan anak-anak dan dinamika keluarga, sampai pada akhirnya terjadi proses reproduksi dan aliansi keluarga. Keluarga juga dapat berfungsi dengan baik apabila memperhatikan faktor yang mempengaruhi reaksi emosional keluarga, pemikiran, keyakinan, sikap, prasangka, relasi, dan perilaku. Sangat penting bagi keluarga memperhatkan isu-isu kultural untuk mengembangkan sikap yang berkaitan dengan individu dan komunitas, pengambilan keputusan, jenis kelamin dan gender, persepsi, penggunaan bahasa, spiritualitas, siu fisik dan emosional serta pengalaman dan trauma.

Kesadaran pada konsep keluarga dan seluruh kekuatan yang ada pada keluarga menjadikan proses interaksi dan komunikasi keluarga menjadi lebih intim dan kebutuhan terpenuhi. Berbagai ahli telah menyadari bahwa keluarga dengan dinamikanya menjadi tempat berlangsungnya perkembangan keintiman, kekuasaan, relasi, pengambilan putusan, pemenuhan kebutuhan psiko-spiritual, dan interdependensi antar anggota keluarga dengan melibatkan feedback dinamis atau keteraturan hubungan secara psikologis dan sosial (Slamet, 1987). Dinamika keluarga penting dibangun mengingat individu tidak akan mungkin hidup sendiri dalam masyarakat, bekerja sendiri dalam memenuhi kebutuhan, pembagian kerja yang jelas agar pekerjaan terselesaikan, berjalannya demokratisasi yang efektif pada lembaga sosial. Dinamika dalam keluarga membantu mengklarifikasikan tanggung jawab dan kewajiban anggota keluarga. Pada konteks selanjutnnya dinamika keluarga menjadi cara terpenting untuk membentuk perilaku dan pikiran anggota keluarga dalam rangka pemenuhan kebutuhan psikologis, material, sosial, dan spiritual (Arifin, 2015).

\section{Konseling Perkawinan}

Konseling perkawinan sering diidentikkan dengan konseling keluarga. Zaini (2014) menyebutkan bahwa bimbingan perkawinan dipahami sebagai proses pemberian bimbingan dan bantuan untuk mengubah dan membangun hubungan keluarga guna mencapai keharmonisan (Zaini, 2014). Konseling perkawinan melibatkan fungsi-fungsi terapi dalam keluarga. Fungsi terapi yang dibentuk dalam konseling perkawinan adalah bagaimana fungsi relasi yang ada pada keluarga dapat dijalankan, dan dimanfaatkan untuk mencegah, menangani problem relasi dan hubungan kekeluargaan, selanjutnya mengembangkan hubungan saling menguntungkan demi keharmonisan dan kesejahteraan. Konseling perkawinan seperti diungkapkan Kathrin Geldard dan David Geldard bertujuan membangun kesadaran keluarga baik dalam pola relasinnya, komunikasi, pola hubungan, dan aliansi mengatasi masalah 
(Geldard \& Geldard, 2005). Proses ini penting dilakukan mengingat keluarga bagian paling urgen sebagai pembentuk kekuatan masyarakat.

Konseling perkawinan mengarahkan anggota keluarga menyadari fungsi, peran dan tanggung jawab individu dalam keluarganya. Kehidupan perkawinan harus dijalankan dengan landasan tanggung jawab, peran, kekuasaan yang sesuai dengan kaidah norma yang berlaku di masyarakat maupun ajaran agama. Arah selanjutnya menjadikan kehidupan perkawinan selalu diliputi dengan rasa aman, nyaman, tenteram, dan bahagia. Konteks pemberian layanan konseling perkawinan diorientasikan pada prinsip-prinsip preventif dan kuratif. Artinya bahwa konseling perkawinan digunakan sebagai bekal calon pasangan (suami-istri) untuk mencegah dan menangani masalah yang akan ditimbulkan dalam kehidupan perkawinan. Menyadari pentingnya relasi dan koalisi masing-masing subsistem keluarga, serta mengatasi berbagai kemungkinan kondisi rawan konflik dalam kehidupan perkawinan. Eksistensi kehidupan pernikahan akan dapat diukur dari kualitas relasi antar individu dan keharmonisan yang terjadi di dalamnya. Ini menunjukkan bahwa konseling perkawinan menjadi upaya terapi bagi pasangan untuk menyadari situasi dan melengkapi dengan upaya solutif secara mandiri dan berkelanjutan.

Bowen (1978) menyebutkan bahwa proses terapi yang terlibat dalam konseling perkawinan adalah terapi naratif dan berorientasi pada pemecahan masalah beserta alternatifnya. Teorinya berkembang dari praktik dan prinsip struktur pembentuk keluarga serta kelekatan yang terbangun dalam keluarga yang diadopsi dari psikoanalisis. Terdapat lima model dalam konseling perkawinan yang menekankan pada relasi keluarga yaitu terapi keluarga multigenerasi, strategis, eksperiensal, struktural, dan konstruktif (Bowen, 1993). Terapi keluarga multigenerasi memusatkan perhatian membantu keluarga mengembangkan wawasan-wawasan kehidupan perkawinan. Pemikiran utamanya diberikan pada pentingnya differentiating anggota keluarga. Diferentiating memaparkan pada pembeda konsep intrapsikis dan interpersonal pada keluarga (Bowen, 1993). Dinamika keluarga yang terbentuk pada kehidupan perkawinan ditularkan dari satu generasi ke generasi berikutnya. Cara untuk mengubah masalah kehidupan perkawinan dengan mengubah interaksi-interaksi individu dengan keluarga asalnya. Kelekatan pada keluarga asal harus diputuskan sebagai upaya diferensiasi diri karena dapat membebaskan kelekatan emosional yang justru akan melahirkan konflik antar keluarga (Bowlby, 1951).

Terapi keluarga strategis adalah terapi yang mendasarkan pada pemanfaatan sibernetika untuk menjelaskan dinamika keluarga. Konsep sibernetik memberikan keterangan masalah dalam keluarga pada saat keluarga menunjukkan reaksi terhadap suatu masalah, dan menerapkan solusi yang tepat atas masalah. Orientasi terapi yang dilakukan adalah reframing (mengubah sudut pandang suatu perilaku). Konselor pada konsep ini berperan sebagai konsultan ahli yang berfungsi memandu para keluarga mengubah cara berperilaku dalam relasi dengan keluarga lainnya. Layanan yang ada dalam terapi strategis mencakup pemberian nasihat, saran, melatih, member tugas dan melakukan intervensi paradoks (Bowlby, 1951). Intervensi ini merupakan proses reframing yang mengonotasikan masalah dan perilaku anggota keluarga secara simtomatik.

Terapi keluarga eksperiensial bermaksud untuk memaknai eksistensi manusia (keluarga) berdasarkan pada pengalaman-pengalaman pribadi. Pengalam-pengalaman pribadi ini membawa anggota keluarga berhubungan dengan emosi-emosinya selama proses konseling. Orientasi dasarnya mengedepankan adanya keyakinan, kearifan alamiah, komunikasi, emosi yang jujur, akal yang kreatif, bersemangat, penuh cinta, dan bersifat produktif. Keluarga yang sehat dalam pandangan teori ini adalah keluarga yang memberikan keleluasaan individual, tidak mengabaikan kebersamaan, memiliki cukup rasa aman, kasih sayang dan cinta, jujur memelihara perasaan, dan cukup memberikan kebebasan menjadi diri sendiri. Aspek subjektivitas banyak berperan dalam proses terapi eksperiensial. Kondisi ini dilatarbelakangi pada keyakinan bahwa individu dalam keluarga memiliki hak menjadi diri sendiri. Proses terapi mengarahkan individu untuk aktif berkomunikasi melalui emosi-emosinya, melakukan pengungkapan, memunculkan ikatan keluarga, mengutamakan autentisitas. Konselor dalam terapi ini berperan sebagai fasilitator yang membantu klien memperjels komunikasi dalam keluarga dan menjauhkan orang dari keluhan-keluhan menuju pada penemuan solusi. Penguatan rasa harga diri para anggota keluarga dilakukan dengan menekankan pada maksud-maksud positifnya (Satir \& Baldwin, 1993). 
Terapi keluarga structural menekankan pada struktur keluarga, subsistem keluarga, dan batasanbatasan. Keluarga dalam kehidupanperkawinan akan berinteraksi satu dengan yang lainnya dalam rangkainan pola terorganisasi secara spesifik. Keluarga sebagian besar mempunyai struktur hierarkis anatara orang dewasa, dan anak-anak dalam kekuatan dan otoritas berbeda. Struktur hierarki orang dewasa sangat penting dalam rangka mengelola keluarga, sehingga diharapkan mampu mengubah struktur keluarga, dan para anggotanya mampu menyesuaikan diri dengan berbagai kondisi yang berubah serta berkembang. Perubahan struktur yang diharapkan dalam proses konseling harus didasarkan pada struktur keluarga itu sendiri, pola komunikasi dan selanjutnya memodifikasi-pola tersebut. Kerjasama dan koordinasi anggota keluarga dalam terapi ini sangat menentukan sehingga struktur yang terbentuk adalah struktur hasil kerja partisipatif seluruh anggota keluarga.

Terapi keluarga konstruktif mendasarkan pemahaman tentang makna keluarga. Menyadari makna keluarga dilakukan dengan membantu anggota keluarga untuk bergaul dan berinteraksi secara efektif, berkomunikasi dan konstruksi bersama, serta memiliki kepekaan terhadap relasi dan nilai. Praktik konseling ini mengedepankan terjadinya proses refleksi sehingga hal-hal yang diasumsikan tidak membantu dapat ditangguhkan. Akibatnya terapi keluarga membantu terjadinya pergeseran pendekatan dari penerapan pengetahuan menjadi perimbangan nilai-nilai yang inheren. Terjadi adopsi posisi yang awalnya tidak diketahui, tidak ditanyakan menjadi pemahaman dan eksternalisasi masalah, sehingga terbentuk modivikasi solusi atas masalah yang dihadapi keluarga.

Model-model konseling perkawinan memberikan pemahaman bahwa individu dalam keluarga memaindan peran pentingnya secara efektif. Apapun model yang digunakan, muara dari pelaksanaan konseling perkawinan adalah menumbuhkan pemahaman dan kesadaran individu mengani kehidupan perkawinan. Pemahaman dan kesadaran yang meningkat bukan hanya terletak pada keluarga inti melainkan juga pada anggota keluarga lainnya. Keluarga memerlukan upaya peningkatan kesadaran atas apa yang ada dalam kehidupan perikahan, sehingga membawa keluarga dan anggotanya menuju pada posisi kemampuan untuk mengambil keputusan tentang perubahan bagi kehidpan perkawinannya.

\section{Membangun Hubungan Keluarga Sakinah}

Islam sebagai agama dakwah menginginkan kehidupan pernikahan diliputi oleh semangat ketuhanan dan kemanusiaan. Konteks kehidupan pernikahan ini sesuai dengan prinsip dasar pernikahan dalam islam yaitu pernikahan merupakan sunnah rasul, kehidupan pernikahan berkaitan dengan persoalan pengelolaan ekonomi dan kemampuan berusaha, kesesuaian antar pasangan, sendi perekat ikatan perkawinan adalah kasih sayang, kebutuhan dalam perkawinan adalah keintiman secara fisik, sosial, dan emosional (Mubarok, 2000). Mendasarkan pada prinsip dasar konseling perkawinan, maka penanganan relasi keluarga menjadi hal penting mewujudkan keluarga sakinah. Seperti dijelaskan di atas bahwa perkawinan merupakan sunnah rasul. Perintah ini mengandung banyak manfaat bahwa perkawinan merupakan aktualisasi diri sebagai makhluk individu sekaligus sosial. individu memiliki naluri menjadi seorang bapak, dan ibu. Penyaluran naluri alamiah ini harus dilakukan sesuai norma agama dan kaidah sosial dalam satu ikatan perkawinan. Menjadi bapak dan ibu bagi anak-anaknya akan menempa kemandirian dan tanggung jawab sosial, karena pengasuhan anak akan menjadi optimal. Anak-anak tumbuh dalam situasi kondusif, menumbuhkan perasaan emosional berupa kasih, sayang, kesetiaan, dan sifat-sifat yang baik menyempurnakan kemanusiaan seseorang. Perkawinan juga melatih individu memiliki kemandirian dalam memikul tanggung jawab ekonominya. Orang yang sudah masuk kehidupan perkawinan akan memberikan semangat mengelola potensi ekonominya untuk memenuhi kebutuhan keluarga. Pemenuhan kebutuhan hidup akan dilakukan dengan usaha keras, sehingga keluarganya tercukupi dan keberkahan akan melingkupinya. Pernikahan juga menjadikan kehidupan perkawinan sebagai kesesuaian pasangan. Islam menyebutkan bahwa suami dan istri adalah pakaian dan pemakainya. Artinya pasangan dalam perkawinan perlu memperhatikan kesesuaian dan menumbuhkan kesadaran untuk saling bekerjasama. Baik suami maupun istri perlu menjaga kehormatan keluarganya, istri menjaga kehormatan suami, begitu pula sebaliknya. Kondisi ini dalam islam menempatkan aspek etis kehidupan pernikahan, karena pernikahan bukan sarana untuk membuka aib karena perbedaan. Pernikahan adalah sarana untuk menutupi dan mendamaikan perbedaan sebagai rahmat dan karunia terbesar bagi kehidupan selanjutnya. 
Pernikahan yang baik dan berkualitas adalah pernikahan yang diliputi oleh semangat cinta dan kasih sayang. Upaya ini dilakukan untuk mendapatkan ketenteraman, kemanana, dan kesejahteraan. Islam memandang bahwa cinta dan kasih sayang adalah perbuatan luhur, suci karena merupakan anugerah Allah swt. Semangat yang dihadirkan dalam pernikahan yang penuh cinta dan kasih sayang adalah kesabaran, kesetiaan, pengertian dan pemahaman, pemberian, pengorbanan. Hal ini sesuai dengan firman Allah dal quran surat Ali Imran ayat 14.

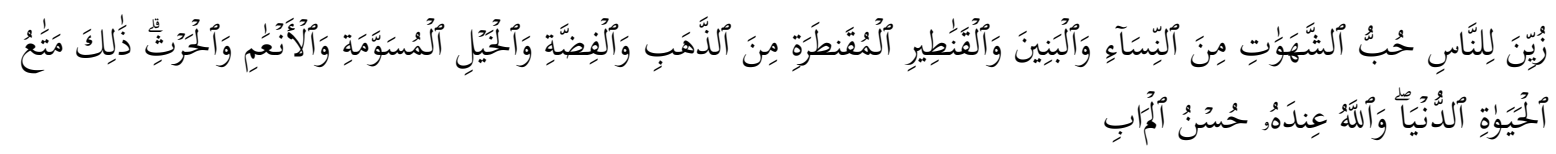

"dijadikan indah pada (pandangan) manusia kecintaan kepada apa-apa yang diingini, Yaitu: wanitawanita, anak-anak, harta yang banyak dari jenis emas, perak, kuda pilihan, binatang-binatang ternak (Mubarok, 2000) dan sawah ladang. Itulah kesenangan hidup di dunia, dan di sisi Allah-lah tempat kembali yang baik (surga).

Ikatan pernikahan adalah sarana menyalurkan cinta dan kasih sayang. Manusia diciptakan dengan jodohnya, dengan dibekali keinginan untuk menjalin hubungan yang baik. upaya ini dilakukan untuk menghasilkan keharmonisan dan tanggungjawab sosial kemanusiaannya. Perkawinan mengikat kebebasan menyalurkan cinta dan kasih sayang secara harmonis dan bertanggungjawab. Perkawinan dalam perspektif ini menghasilkan kehidupan yang penuh dengan ketenangan dan ketenteraman dalam hidup. Ketenangan dan ketenteraman ini tercapai karena perkawinan dapat memelihara diri dari kerusakan jiwa personal dan kemanusiaan. Pada keluarga menikah, menjadikan pribadinya terkontrol pembatasan emosional dan sosial. kondisi ini memungkinkan seorang yang melakukan perkawinan akan cenderung menjalin hubungan secara bertanggung jwab karena memiliki pembatasan emosional yang begitu luar biasa. Individu tidak akan melakukan penyaluran cinta dan kasih sayang secara tidak wajar. Ada pemahaman bahwa penyaluran cinta dan kasih sayang yang tidak wajar akan membawa dampak kerusakan pada dirinya sendiri maupun masyarakatnya. Perkawinan akan mengembalikan dan mengurangi dorongan perbuata yang bertentangan dengan nilai-nilai agama, mengekang hawa nafsu dan dengan kesungguhannya mengelola kehidupan keluarganya dengan sebaik mungkin.

Keluarga yang tenteram, damai, sejahtera menjadi dambaan dan idaman bagi semua orang. Ketenteraman tidak hanya melibatkan aspek intimitas, melainkan juga berkaitan dengan peran dan relasi kuasa. Kehidupan pernikahan yang tenteram di dalamnya melibatkan ketiga aspek tersebut. Aspek keintiman membentuk sikap paham dan sadar mengenai makna dan fungsi keluarga. Aspek peran membentuk kecerdasan dalam mengelola dan mengendellikan kehidupan perkawinan. Aspek relasi kuasa membentuk pola struktur tanggung jawab personal dan sosialnya secara baik dan efisien. Keluarga tenteram dapat diraih apabila seluruh anggota keluarga dapat mencapai ketiga aspek tersebut dan mengimplementasikan prinsip dasar perkawinan sesuai dengan kaidah norma yang diyakini benar. Untuk mewujudkan kehidupan yang tenteram dapat dilakukan dengan konseling perkawinan. Asumsi dasarnya terletak bahwa proses kerja konseling adalah proses yang dilakukan bukan hanya pada individu bermasalah, melainkan dapat dilakukan bagi semua individu yang membutuhkan layanan konseling perkawinan. Tidak menutup kemungkinan bagi keluarga yang sudah harmonis melakukan kegiatan konseling perkawinan, karena kegiatan ini dapat dimanfaatkan untuk mendapatkan informasi dan penyadaran, serta pengembangan potensi anggotaa keluarga. Berdasarkan pada fungsi konseling perkawinan, orientasi kegiatannya tidak hanya sebagai penanganan masalah melainkan terdiri dari fungsi pereventif, kuratif, preservatif, advokatif, dan developmental (Febrini, 2011). Pola hubungan interaksi yang ada dalam kehidupan perkawinan tidak selamanya berjalan mulis, adakalanya menemui hambatan baik dalam skala kecil maupun besar. Konseling perkawinan dalam menjalankan fungsifungsi terapinya, berupaya menjadikan kehidupan keluarga yang penuh keharmonisan dan ketenteraman. Maka melalui fungsi terapis yang ada, dapat diidentifikasi melalui fungsi konseling perkawinan yaitu fungsi preventif, kuratif, preservative, advokatif, dan fungsi developmental sebagai berikut: Pertama, Fungsi preventif dalam interaksi kehidupan perkawinan diarahkan pada upaya antisipasi terjadinya masalah, dengan perbagai varian model dan penyebabnya. Kaitannya dengan membangun keluarga sakinah, proses konseling diarahkan untuk mengenali faktor pemicu lahirnya problem interasi dalam kehidupan keluarga, mulai problem innteraksi individual, subsistem keluarga, sampai apada faktor-faktor lainnya yang masuk dalam persoalan sosial dan cultural. Fungsi preventif 
juga mempersiapkan klien untuk memiliki pengetahuan, penyadaran mengenai pembatasan masalah, keterampilan pengambilan putusan yang terbaik untuk kehidupan perkawinnannya.

Kedua, Fungsi kuratif dalam interaksi kehidupan perkawinan diarahkan pada bagaimana sikap individu memandang masalah yang sedang dihadapi. Pada kondisi ini, individu diarahkan untuk menemukan reframing terhadap problem yang dialaminya. Fungsi kuratif mengarahkan adanya penyesuaian, adopsi dan modifikasi model persoalan, dan solusi masalah yang dihadapi.

Ketiga, Fungsi preservative diarahkan sebagai upaya meningkatkan kualitas kehidupan perkawinnan, sehingga keteraturan dan kesesuaian tanggung jawab dan peran maisng-masing anggota dapat dijalankan secara efektif.

Keempat, Fungsi advokatif diarahkan pada perlindungan masing-masing anggota keluarga dalam kehidupan perkawinan. Fungsi ini diarahkan terjaminnya hak dan kewajiban individu dbagai bagian dari anggota keluarga, baik hak yang bersifat dasar (fisik, dan psikologis), maupun bersifat sosial dan spiritual.

Kelima, Fungsi developmental diarahkan pada penguatan kapasitas kehidupan perkawinan, dan pemberdayaan potensi keluarga. Dalam hal ini lebih mengarah pada upaya untuk memberdayakan pola interaksi dan komunikasi yang ada dalam keluarga, sehingga keluarga tersebut benar-benar mendapatkan kesejahteraan lahir dan batin sesuai dengan kaidah ajaran agama. Terapi pengembangan dalam konseling perkawinan diarahkan pada keterampilan untuk menjadi keluarga yang mandiri dan berdaya saing.

Mendasarkan fungsi konseling perkawinan didapatkan pemahaman bahwa proses yang terjadi bukan hanya sekedar penanganan masalah kehidupan perkawinan, malainkan mengarahkan individu benar-benar memahami makna, kedudukan, memiliki pemahaman dan kesadaran, serta orientasi yang benar mengenai perkawinan (Gunawan, 1992). Model konseling yang telah dijelaskan di atas membantu individu dalam keluarga menyadari pentingnya persoalan relasi dan interaksi keluarga dalam kehidupan pernikahan. Relasi dan interaksi menjadi probem yang sering muncul dalam kehidupan perkawinan. Keluarga yang penuh dengan ketenteraman (sakinah), cinta (mawaddah), dan kasih sayang (rahmah) dapat dikenali melalui kualitas hubungan dan interaksi dalam keluarganya. Semakin baik kualitas interaksi dan hubungan antar anggota keluarga, maka akan semakin berkualitas kehidupan perkawinannya, selanjutnya kehidupan sakinah, mawaddah, dan rahmah dapat diwujudkan dalam kehidupan.

\section{REFERENSI}

Arifin, B. S. (2015). Dinamika kelompok. Pustaka Setia.

Bowen, M. (1993). Family therapy in clinical practice. Jason Aronson.

Bowlby, J. (1951). Maternal care and mental health (Vol. 2). World Health Organization Geneva.

Etzioni, A. (1994). Spirit of community. Simon and Schuster.

Febrini, D. (2011). Bimbingan konseling. Teras.

Geldard, K. (2009). Konseling keluarga: membangun relasi untuk saling memandirikan antaranggota keluarga. Pustaka Pelajar.

Geldard, K., \& Geldard, D. (2005). Practical counselling skills: An integrative approach. Macmillan International Higher Education.

Geldard, K., \& Geldard, D. (2011). Keterampilan praktik konseling: pendekatan integratif. In Yogyakarta: Pustaka Pelajar. Pustaka Pelajar.

Gunawan, Y. (1992). Pengantar bimbingan dan konseling. PT. Gramedia.

Hariwijaya, H. (2011). Menjadi diri sendiri guna meraih puncak prestasi strategi membangun citra diri. Oriza.

Hasanah, H. (2013). Peran strategis aktivis Nurul Jannah al Firdaus dalam membangun kesadaran beragama perempuan kota. Jurnal Keislaman Inferensi STAIN Salatiga, 7(2).

Lubis, S. A. (2007). Konseling Islami: Kyai \& pesantren. eLSAQ Press. 
Mubarok, A. (2000). Al Irsyad an Nafsy: konseling agama teori dan kasus. Bina Rena Pariwara.

Satir, V. M., \& Baldwin, M. (1993). A guide to creating change in families. Science dan Behavior Books.

Slamet, S. (1987). Dinamika Kelompok (Vol. 123). Fakultas Pascasarjana-Institut Pertanian Bogor. Thanthawi, M. S., Kamali, A. Z., \& Zaid, A. H. (2001). Etika dialog dalam Islam. Mustaqiim.

Umriana, A., Fauzi, M., \& Hasanah, H. (2017). Penguatan hak asasi perempuan dan kesetaraan gender melalui dialog warga. Sawwa: Jurnal Studi Gender, 12(1), 41-60.

Zaini, A. (2014). Membentuk keluarga sakinah melalui bimbingan dan konseling perkawinan. Jurnal Konseling Islam. STAIN KUDUS, 5(1). 